Article

\title{
Sustainable Event Planning: An Exploration of University Conference Centers
}

\author{
Madeline Samuel ${ }^{1}$, Hyunsuk Choi ${ }^{2, *}$, Haesang Kang ${ }^{3}$ and Myong Jae Lee ${ }^{1}$ \\ 1 The Collins College of Hospitality Management, California State Polytechnic University Pomona, \\ Pomona, CA 91768, USA; masamuel@csupomona.edu (M.S.); mjlee@cpp.edu (M.J.L.) \\ 2 The Program of Tourism and Hospitality Management, School of Business, Black Hills State University, \\ Spearfish, SD 57799, USA \\ 3 The Department of Event \& Convention, Division of Tourism, Dongseo University, Busan 47011, Korea; \\ eventpia@gdsu.dongseo.ac.kr \\ * Correspondence: hyunsuk.choi@bhsu.edu
}

Citation: Samuel, M.; Choi, H.; Kang,

H.; Lee, M.J. Sustainable Event

Planning: An Exploration of

University Conference Centers.

Sustainability 2021, 13, 7194. https://

doi.org/10.3390/su13137194

Academic Editors: Kwangsoo Park and Seunghyun "Brian" Park

Received: 26 May 2021

Accepted: 23 June 2021

Published: 26 June 2021

Publisher's Note: MDPI stays neutral with regard to jurisdictional claims in published maps and institutional affiliations.

Copyright: (c) 2021 by the authors. Licensee MDPI, Basel, Switzerland. This article is an open access article distributed under the terms and conditions of the Creative Commons Attribution (CC BY) license (https:/ / creativecommons.org/licenses/by/ $4.0 /)$.

\begin{abstract}
The use of conference services on university campuses has grown in recent years. Focusing on three university conference centers in Southern California in the United States, this study explores innovative practices, tools, and strategies that sales and marketing teams can use to attract potential clients to campus facilities. A Delphi method with a panel of eight sales and marketing experts from three university conference centers was used to examine tools and strategies used by university conference centers. The findings reveal that email marketing, tradeshows, and social media are effective marketing tools to show that universities are an economical option for meeting planners, providing meeting attendees with the college atmosphere that they would not receive at a hotel. Detailed implications of results are discussed.
\end{abstract}

Keywords: university conference centers; marketing strategies; meeting planners; Delphi method

\section{Introduction}

The meeting and event industry is becoming increasingly competitive and significant in hospitality. Meetings and events benefit attendees, companies, and the cities that host them, while also promoting networking, strengthening relationships, and providing opportunities for learning and sharing industry knowledge [1-4]. In the United States, many new conference and convention centers have been built, while many existing conference spaces have been renovated to reflect current meeting industry trends $[5,6]$. There were 250 convention centers in the United States in 2017 [7]. According to Jensen et al. [6], as of 2015, eighteen convention and conference centers in the U.S. were under construction; five were new builds and thirteen were classified as expansion projects. Additionally, thirty-one centers in the U.S. were proposed as new projects to commence before 2020.

The meeting and event industry should continue to grow and contribute to the local and national economies of host destinations [8-10]. According to Oxford Economics [11], 1.9 million meetings and events comprised of 251 million participants occurred in the United States in 2016, and travel for those meetings and events accounted for about $\$ 120$ billion of business travel. The direct spending on meetings has increased 23 percent between 2009 and 2016.

As the meeting and event industry has grown, meeting venues must increasingly provide a variety of services, including lodging and meal options. Under these circumstances, conference facilities on university campuses have become a popular choice for meeting planners [12-14]. According to the International Association of Conference Centers [15], using college and university conference facilities increased by $7.2 \%$ from 2014 to 2015 worldwide. One reason for this increase could be the value of university conference centers. Overall, prices for food, accommodations, and meeting space at university 
conference centers are more attractive for meeting planners than comparable packages in hotels, convention centers, and/or dedicated conference centers [16]. By hosting their annual meetings and conventions at university conference centers, meeting planners can save $10-15 \%$ of the total costs. In addition, university conference centers often do not charge hotel or sales taxes, which also saves money on other expenses [17]. In addition, the main draw for academic venues is prestige, location and accessibility, superior learning environments, diverse meeting spaces, cutting-edge technology, recreational space, and corporate social responsibility [14]. Most universities have outdoor areas, gym facilities, pools, various meeting spaces, and dining services, which makes universities an ideal place for meeting planners to plan meetings and events [18].

Various studies have focused on how meeting planners gather the needed information about potential meeting destinations and venues and select a location [19-21]. Unfortunately, however, little has been researched on the use of meeting facilities on university campuses and how universities market their meeting facilities to attract potential clients. In the competitive meeting market environment, university conference and sales teams must understand how to provide meeting planners with the information they need to choose a conference location. Therefore, the purpose of this exploratory study is to identify the sales and marketing tools and strategies used by university conference centers in Southern California in the United States. Using a Delphi method with a panel of eight sales and marketing experts from three university conference centers, this research focused on determining which marketing techniques are popularly used by university conference centers to attract clients; which tools are most beneficial; and how these tools help a university stand out from competing venues.

\section{Literature Review}

\subsection{University Meeting Facilities}

While larger events tend to choose major meeting destinations and highly-rated private venues, universities and colleges are competing for other meetings and conventions, and meeting planners consider university meeting facilities in the site selection process $[22,23]$. College towns represent a distinctly urban environment with their diversity, educated population, and strong infrastructure [24]. College campuses and surrounding towns are built to accommodate heavy foot traffic throughout and around the campus from students, staff, faculty, or visitors $[25,26]$. Meeting planners who want to reduce costs for lodging, meals, and other meeting services consider universities as potential meeting and event venues $[18,26]$.

Universities provide more than an academic setting for students and faculty. Unlike hotels and convention centers, universities present large meeting facilities and complimentary meeting spaces throughout the campus to often include outdoor fields, gymnasiums, art centers, and different sizes of lecture halls [12-14,27]. University meetings and events departments provide corporate and/or association meeting planners with many opportunities to coordinate meetings and conferences on campus. While corporations and associations may look at universities as a setting better suited to younger or academicoriented groups, other groups with small budgets and large guest lists can generally find a happy medium choosing a university as the host venue [20].

\subsection{Marketing Tools}

Venue operators commonly use various marketing tools, such as word-of-mouth (WOM), traditional media, trade shows, digital media, television commercials, the internet, public relations, and social media [28-30]. These tools communicate information, fuel customer curiosity, and provoke action [31,32].

Word-of-mouth is the most influential source of information for meeting planners during the site selection process [33-35]. Venue operators consider each meeting planner and meeting attendee as a potential source of marketing influence [36]. Meeting planners spread words about the locations, meeting facility, prices, and various meeting services to 
fellow meeting planners. This recommendation affects brand awareness and eventually business leads [37].

Venue operators commonly use traditional media that include newspaper advertisements, brochures, television commercials, radio advertisements, and magazines. Traditional media can be effective in local marketing. Chiu and Ananzeh [38] revealed that when searching for travel information, local respondents perceived newspaper and TV/radio advertisements highly, compared with international respondents who perceived internet, public relations, and WOM higher. However, today's venue operators have slowed their use of this traditional marketing tool. An empirical study of 200 meeting professionals revealed that traditional meeting outlets, such as brochures and newspaper advertisements, are the least influential sources affecting meeting planners [39]. Furthermore, collateral material, direct mail, and printed material were ranked among the lowest of media forms that influence an event planner's decision to host a meeting or conference at a particular venue [39].

Trade shows are still a popular marketing tool for venue operators [40]. At trade shows, venue operators interact with meeting planners and introduce new products, venues, and amenities, while meeting planners attend trade shows to create a new direction for proposed events and search for new destinations, venues, and vendors [41].

Digital media includes the internet and mobile technology. Venue operators increasingly use information technology and online marketing [35,38,42]. Wang and Fesenmaier [43] revealed that visual content, online registration options, and adequate information on amenities have a positive influence on the site selection process. In the same study, they concluded that accommodation information and activities/attraction information were among the most effective features of a conference venue website. Solaris [44] claimed that $58 \%$ of marketers use social media for marketing before, during, and after their events. Social media, such as Twitter, LinkedIn, Facebook, mobile applications, and Instagram, allow real-time connectivity between venue operators and meeting planners, helping venue operators spread venue information to thousands of meeting planners with a click of a button $[45,46]$.

\subsection{Information Content}

The information content provided by each of these marketing tools is a major component of whether or not the clients are influenced to choose a particular meeting site [47]. Understanding exactly what potential sites have to offer is the first step that meeting planners undertake in meeting planning [39]. The meeting planner-driven marketing concept and the increasingly competitive market environment make it necessary for venue operators to understand the information search behaviors of potential clients [48,49].

In evaluating event venue websites, Lee, Kim, and Parrish [50] revealed that on-site catering, types of events hosted, parking information, capacity, the layout of the space, and pricing are key information provided by venue operators. Alexander et al. [39] asserted that meeting planners' site selection process involves more than one influential information factor. In an empirical study of 200 meeting planners, they revealed that information on meeting rooms, cost of facilities, and attractive location were the top three influences for site selection [39]. In addition, Mayaka [51] revealed that destination image and accessibility are the keys to site selection. Lee and Lee [52] studied the selection attributes of convention and exhibition centers from the perspective of exhibition organizers. In this study, the most important factors were exhibition hall cost, center facilities, convention and exhibition center staff members, and service contractors. Meeting planners rated travel tips, dining facilities, and ease of accessibility as the information most needed for the pre-decision process [53]. They concluded that meeting planners who have not decided on a final meeting site were more likely to be interested in the information that differentiates the site being considered from other potential sites [53].

Venue operators must identify current meeting trends and understand how they affect meeting planners in collecting information and evaluating venues. With the growing use of 
the Internet, venue operators should look at what type of information is included on their websites [54]. Catering menus, an option to submit a request for proposal (RFP) online, and pricing information are the types of information meeting planners commonly need. Additionally, an online tool to let meeting planners request a proposal was an important marketing strategy for host destinations [50]. Not only does this provide a meeting planner with an easy way to access the venue, but also it can help the salesperson at the venue design a meeting based on meeting planners' needs.

\section{Methodology}

\subsection{Delphi Method}

The main data analysis tool used in this study was the Delphi method, which is a group decision-making process that acquires data based on the judgments of experts [55]. The Delphi method is a popular research tool when insufficient knowledge exists on a question or problem. The Delphi technique is especially helpful when the research objective is to enhance the understanding of issues, opportunities, and answers to problems, or to develop forecasts [56]. Because marketing tools for university conference centers have not seen significant research, the Delphi method can help convention researchers gain a better understanding of university conference centers through the opinions of a panel of experts. Following the process formulated by Ritchie and Goeldner [57], this study used the following steps of the general Delphi approach: (1) Identify an issue, (2) Formulate questions through a variety of sources, (3) Select a panel of experts, (4) Distribute questionnaires, (5) Study and summarize the data, (6) Redistribute summaries to experts several times, and (7) Perform data analysis in which each question is answered through a summary of agreed-upon responses [58,59].

\subsection{Questionnaire Development}

Through a review of the existing literature on meetings and events, and in-depth discussions with industry representatives including members of Meeting Professionals International (MPI), hospitality management professors, and university conference center employees, a total of twelve interview questions about marketing tools used by university conference centers were initially formulated. After an additional panel discussion, two of the twelve questions were consolidated because they could provide the same answers, resulting in eleven questions in five categories (marketing tools, clientele, content information, trends, and challenges) for the final questionnaire. The final questionnaire also contained five socio-demographic questions. (See Appendix A).

\subsection{Data Collection}

The panel of experts was chosen by calling the conference and/or event department of three universities located in Southern California that operate a conference center on campus. A total of eight conference sales and marketing managers and directors agreed to participate in this study. They were sent a preliminary email describing the method, the study's purpose, and what would be expected of each of them. Later, the link to the questionnaire, which included the eleven open-ended questions and the five demographic questions, was distributed via email to the panel. The panel was given two weeks to submit answers for the first round of questions. Once submitted, the answers for each question were analyzed, compiled, summarized, and placed in a document. Then, panelists were emailed the document and asked to review the feedback given by every other panelist, as well as the summary created from the compiled data. After the review, the panel provided additional comments, discussions, and opinions based on feedback from the other panelists. Any new feedback was highlighted in the summaries to help panelists understand where the summaries and discussions were revised after the first round. Panelists either provided feedback via email or printed out the documents, wrote down notes and revisions, then scanned and emailed back the paperwork. 


\subsection{Data Analysis}

Once the first round of data coding was completed, the textual data were coded again in a different period for intra-rater reliability [60]. Then, the collected data were read through carefully by three additional reviewers to ensure the validity of the coding process [61]. If more than one panelist mentioned a specific item or had a similar opinion to another panelist, the similarities were noted in a document. The responses were analyzed using keywords and counting the number of times these words were mentioned for each question. By organizing the responses to each question with these keywords, some content could be eliminated from the summary depending on how many times a word was mentioned under each panelist's response to a particular question. If a keyword was only mentioned by one panelist for a specific question, without indication as to why it was important, that piece of information was most likely not included in the summary because it did not represent the panel's agreed-upon opinion. However, answers that were mentioned by only one panelist but followed by a quality explanation as to why it was an appropriate answer to the question were included in the summary for further review in future rounds. The keywords were then analyzed in summary form using the panelists explanations for each answer. Each summary was written to reflect the services offered by university campuses and emphasize what was unique to venues on university campuses.

Once the summaries were completed, sent to the panelists, and returned, the notes and feedback that each panelist submitted were considered for the next round. For this round, most new information was included in the revised summaries, even if mentioned by only one panelist, unless it lacked explanation. Any new information was highlighted for the panelists to read easily. The revised document was then sent to the panelists until each reviewer was content with the summaries, believing that such summaries represented the proper marketing tools, clientele, information content, trends, and challenges each university used to attract an audience and stand out from competing properties.

\section{Results}

\subsection{Demographic Profiles of Respondents}

Table 1 shows the demographic profiles of the eight panelists from three different university conference centers located in Southern California. As for job title, four panelists held the title of director (two directors of sales and marketing and two directors of conference centers). Three panelists were conference services and sales managers, and one was a marketing manager. Two panelists had more than 10 years experience in their current position, two panelists had 8-10 years, three panelists had 3-7 years, while only one panelist had less than 2 years of experience in the position. Overall event and convention industry experiences showed two panelists had worked in the hospitality industry for 6-10 years, another two panelists for 10-20 years, and four panelists for more than 20 years. Additionally, five panelists had experience working in hotels or conference centers outside the university setting.

Table 1. Interview Panels' Demographic Profiles $(\mathrm{N}=8)$.

\begin{tabular}{ccc}
\hline Variable & Number of Respondents & Percentage of Respondents \\
\hline Participating Venue & 4 & $50 \%$ \\
University Conference Center A & 2 & $25 \%$ \\
University Conference Center B & 2 & $25 \%$ \\
University Conference Center C & 2 & $25 \%$ \\
Job Title & 2 & $25 \%$ \\
Director of Sales \& Marketing & 3 & $37 \%$ \\
Director of Conference Center & 1 & $13 \%$ \\
Conference Manager & 2 & \\
Marketing Manager & & \\
\hline
\end{tabular}


Table 1. Cont.

\begin{tabular}{ccc}
\hline Variable & Number of Respondents & Percentage of Respondents \\
\hline Years Worked in the Current Job & 1 & $13 \%$ \\
0-2 years & 3 & $37 \%$ \\
3-7 years & 2 & $25 \%$ \\
8-10 years & 2 & $25 \%$ \\
+10 years & 2 & $25 \%$ \\
Years Worked in the Meeting Industry & 2 & $25 \%$ \\
6-10 years & 4 & $50 \%$ \\
+20 years & 4 years & $53 \%$ \\
Yes & 5 & $37 \%$ \\
No & 3 & \\
\hline
\end{tabular}

\subsection{Marketing Tools}

Under the marketing tools section of the questionnaire, participants were asked to describe the tools they used to market the university conference services (Question 1A) and which tools they found most beneficial for attracting clients (Question 1B). Participant responses showed several similarities as well as a few differences when it came to the types of marketing tools they employed. Table 2 shows that six out of eight participants used social media and university websites as a primary marketing tool. Social media platforms mentioned include Instagram, Twitter, and Facebook. Five out of eight participants responded that they commonly used word-of-mouth and trade shows to help market their university conference facilities. In addition, half the participants responded that they also used email and printed materials, such as magazine advertisements and brochures at trade shows as a marketing tool. Internal networking, such as working with campus departments, was mentioned by three participants. Three panelists used the university's reputation as a marketing tool, finding it beneficial for attracting audiences. Other panelists stated that the reputation of the university is an effective marketing tool when specific qualities of the university are highlighted such as research awards or successful athletic programs. Other marketing tools mentioned included search optimization engines, marketing partners, such as local CVBs, and chambers of commerce. Among these marketing tools, the most beneficial tool was word-of-mouth (4). On the other hand, the least beneficial tool was printed materials (3). Later in the survey, the participants reflect on how these marketing tools impact the clientele.

Table 2. Marketing Tools Used by University Conference Centers.

\begin{tabular}{|c|c|c|}
\hline Marketing Tool & Number of Respondents & Percentage of Respondents \\
\hline Trade Shows & 5 & $63 \%$ \\
\hline Social Media & 6 & $75 \%$ \\
\hline Word of Mouth ${ }^{1}$ & 5 & $63 \%$ \\
\hline University Website & 6 & $75 \%$ \\
\hline Email & 4 & $50 \%$ \\
\hline Personal/Internal Networking & 3 & $37 \%$ \\
\hline Printed Materials ${ }^{2}$ & 4 & $50 \%$ \\
\hline Others & 4 & $50 \%$ \\
\hline
\end{tabular}

${ }^{1}$ Most beneficial marketing tool (5), ${ }^{2}$ Least beneficial marketing tool (3).

\subsection{Clientele}

Under the clientele section of the questionnaire, the panels were asked to describe the types of clientele that often book business at their universities (Question 2A), how the universities best reach these clients (Question 2B), and if they do measure, which tools work best with the clients (Question 2C). Once the data was gathered, the type of clientele was 
divided into five categories: campus-affiliated, external organization, location-based, repeat customers, and age range (See Table 3). The entire panel of experts agreed that much of their conference business came from groups affiliated with the university, such as academic conferences, department internships, research groups, university-hosted sports camps, etc. Six out of eight panelists mentioned that $70-85 \%$ of clients are repeat groups that come back annually. The remaining groups are new clients that universities attract each year. As for non-campus affiliations, five respondents mentioned that external organizations not affiliated with the campus also use their university conference facilities on a regular basis. Two of these five respondents described the location as the main attraction for external organizations hosting conferences at the university, especially when attending nearby events or classes. Lastly, two panelists responded that their conference facilities cover a wide age spectrum of people, ranging from children and youth groups attending summer camps to seniors attending social events, as well as military, educational, religious, fraternal (SMERF), corporate, or association conferences.

Table 3. Types of Clientele Using University Conference Centers.

\begin{tabular}{ccc}
\hline Type of Clientele & Number of Respondents & Percentage of Respondents \\
\hline Campus-Affiliated & 8 & $100 \%$ \\
External Organizations & 5 & $63 \%$ \\
Location-based & 2 & $25 \%$ \\
Repeat Group & 6 & $75 \%$ \\
Age Range & 2 & $25 \%$ \\
\hline
\end{tabular}

The panelists then provided insight on which marketing tools work best for specific groups. For campus-affiliated groups, five of eight panelists agreed that email marketing and social media were beneficial when attracting repeat business. For repeat groups, social media is useful for keeping clients up-to-date on services and reminding them of important events or deadlines approaching. However, social media was not beneficial for attracting new groups because new clients are unaware of the conference location. When referring to age range, two panelists mentioned that social media was better for targeting younger groups while email marketing and trade shows were more beneficial when targeting older or newer groups. All panelists agreed that the website for their conference services is beneficial for all groups because it provides answers to basic questions about the property.

As for measuring whether marketing tools used for particular clientele were working, panelists' answers varied. Six of eight participants shared that they have a return-oninvestment (ROI) tool that can be used for their email campaigns. One panelist noted that when calls come in about conferences, the sales personnel ask how the client heard about their services. Another panelist responded that assessing "likes" or "follows" via social media is an easy way to see how clients are engaging with the venue.

\subsection{Information Content}

When panelists were asked about the type of information provided to clients via these marketing tools (Question 3A), most agreed that content is similar to what many lodging facilities publish. Amenities such as accommodations, nearby tourist attractions, pictures of meeting and venue spaces, as well as dining and catering options were important to include on the website or in brochures. One panelist mentioned that the university posts photos of recent events and conferences on social media outlets to provide an "inside look" at what the university can produce. As for meeting space, universities are sure to provide capacity charts and a variety of audio/visual options to show their expertise in handling various kinds of meetings like banquets, lectures, and team-building workshops. Two of the six panelists responded that the one item they do not publish online is specific rates because rates change based on the seasonality and the type of group (university-affiliated or external). However, rates are showcased during a sales call or in-person meeting. 
The panelists were then asked what type of information they believed should be provided to clients to stand out from outside competitors (Question 3B). Responses were divided into four categories (See Table 4): rates, university mission, experience, and reputation. All eight panelists agreed that to stand out from hotels and other competing venues, they must showcase the pricing advantages. University lodging and meeting room rates are generally more affordable than what hotels and convention/conference centers offer. Additionally, for some universities, groups are not charged occupancy tax or service charges. Three of the eight panelists explained that universities take the revenue earned from conferences and give it back to support the school's mission. Four of the panelists also agreed that hosting a conference on their university campus gives guests a "college experience" feeling, which is exciting for both younger and older groups. Finally, four of the eight panelists also mentioned the reputation of the university as an important highlight to draw clientele. The panelists' understanding of their universities as complex systems, allowed them to more accurately pinpoint meeting trends.

Table 4. Information Contents Provided by University Conference Centers.

\begin{tabular}{ccc}
\hline Type of Information & Number of Respondents & Percentage of Respondents \\
\hline Rates (Lodging \& Meeting Rooms) & 8 & $100 \%$ \\
University Mission & 3 & $37 \%$ \\
College Experiences & 4 & $50 \%$ \\
Reputation of University & 4 & $50 \%$ \\
\hline
\end{tabular}

\subsection{Meeting Trends}

When asked about the current trends related to university conference facilities (Question 4A), all panelists agreed that using technology, more than anything, helps in marketing university conference services. Five of eight panelists agreed that sustainability or environment-friendly practices have become a major factor for meeting planners when choosing a host destination and venue. For example, conference centers' efforts for energy conservation, waste management, eco-friendliness, and water consumption were positively perceived and considered by meeting planners. Two of eight panelists pointed out that social responsibility, or the idea of balancing profit-making activities with society-benefiting activities, is another trend affecting university conference operation (See Table 5). The panelists believed that universities often get high marks on sustainability and social responsibility because many colleges and prospective students value and commit to the environment and help the surrounding community through volunteer work.

Table 5. Trends at University Conference Centers.

\begin{tabular}{ccc}
\hline Type of Information & Number of Respondents & Percentage of Respondents \\
\hline Technology & 8 & $100 \%$ \\
Sustainability/Environment-Friendly Practices & 5 & $63 \%$ \\
Social Responsibility & 2 & $25 \%$ \\
\hline
\end{tabular}

As for future opportunities for university conference centers (Question 4B), seven out of eight panelists mentioned that promoting pricing advantages for meeting groups would continue to help universities stand out from competitors. In addition, marketing the university location and educational setting will continue to benefit university venues as colleges becoming more sophisticated in their technology, facilities, and services. Overall, the panelists agreed that there are, and will be, plenty of opportunities for universities to grow and flourish based on current and upcoming trends.

\subsection{Challenges}

The panelists agreed that university conference centers face three main challenges (Question 5A). First, the educational goal of a university might discourage clients from 
choosing an academic campus as a conference location. In other words, university conference centers are not the first type of venue that non-educational groups would consider for their meetings. Moreover, the panel agreed that while the campus location has many selling points, not all groups are entirely convinced that hosting their conference in an educational setting is a good idea. Tour groups, clients looking for resort-style amenities, and corporations who prioritize luxury may be more likely to choose a hotel or resort that better meets their needs, fulfilling their vision for the conference and its attendees.

Another challenge for university conference centers relates to the resources provided by the university to the conference department to market their services. Hotels and convention centers often have more funding than university conference centers, possibly because a university is likely to spend more of its marketing budget on the university as a whole, not just for guests attending meetings. A hotel, on the other hand, has a primary goal of attracting guests to lodge, dine, and host meetings on the property. Moreover, periodic remodeling and renovation can shut down an entire university building, so the availability of lodging spaces on campus can also be limited, especially for universities that only offer their conference services during the summer.

University conference teams are constantly looking for ways to improve marketing efforts (Question 5B). Three of eight panelists discussed that increasing their presence at trade shows like the Religious Conference Management Association (RCMA) is an important marketing effort. Six of the eight panelists agreed that becoming more familiar with the benefits of social media while capitalizing on sustainability efforts to attract a younger crowd to the universities will increase business. Overall, the panel agreed that continuing to move faster in getting information out to targeted audiences through emails and social media should always be a priority when competing with hotels and other competing venues that concentrate solely on lodging and meeting space.

\section{Discussion}

\subsection{Marketing Tools}

Considering limited marketing budgets and specific target clients, university conference centers must be selective in choosing the best marketing tools to successfully attract clients to campus. The results of this exploratory study indicate that social media, word-of-mouth (WOM), websites, and trade shows are popular marketing tools used by university conference centers. This finding is slightly different from previous event research in which the Internet, WOM, and public relations were highly ranked as important promotional tools $[38,39]$. However, overall, the finding supports previous research indicating that recently venue operators have slowed their use of traditional marketing tools, such as brochures, newspaper advertisements, [39] and trade shows [40,41]; instead, digital media $[35,38,42-46]$ is becoming a popular marketing tool for venue operators.

Social media outlets such as Instagram, Facebook, and Twitter provide an easy way to connect with university clients about property updates, new services offered, and local amenities. The regular use of email blasts is commonly used to market to return clients. Printed collateral materials, such as magazine advertisements or trade show brochures, are still used; however, they are a less-utilized primary source of marketing because of environmentally-friendly policies and technological advances. Other marketing tools used by university conference centers include search engine optimization (SEO), trade publications, and small business fairs.

Unlike hotels and other competing venues, university conference centers can leverage the reputation of the university as a competitive marketing tool. For example, if a school is known for its athletics, the university conference team can promote the achievements of its athletic program and its facilities to host sporting events. It is a common practice for the university conference team to collaborate with the university's reputable athletic program to host sports camps for children who will use campus facilities such as fitness centers, athletic fields, or various athletic courts around campus. By using the school's reputation, whether it relates to academics, research, athletics, or campus architecture, 
conference marketing teams can tailor the campus experience to the goals and missions of specific organizations.

While all these marketing tools serve different purposes when marketing conference services to target audiences, participants of the study found that some tools were more likely to appeal to a particular clientele than others. Most of the professionals agreed that word-of-mouth is the most effective tool, especially for small markets like university conference departments or other education-based properties. Word-of-mouth is a reliable and powerful marketing tool because clients tend to share first-hand experiences with potential clients [35]. Social media is considered as digital word-of-mouth because when individuals engage with social media outlets, they look to gain more information from past clients about the university experience and accommodations. Social media can be useful in attracting younger audiences in particular. It is important for venue operators to encourage current clients to share their reviews online or with other organizations. Once potential clients hear about university conference facilities, websites are most useful for meeting planners to collect detailed information about conference services [43]. For university conference centers working primarily with campus academic departments, email blasts are beneficial because they target a specific client base and encourage them to try new services.

\subsection{Clientele}

For universities, using the correct marketing tools is extremely important for attracting clients that normally would choose to hold their conferences at a hotel. While universities may be competing for the same audience as many other nearby hotels or conference venues, many of their target groups are internal and external repeat clients that focus on educational programs or purposes. At times, university conferences will prioritize campus-affiliated groups if they are running low on availability because it is required by the university. Thus, many new external or non-educational groups may be forced to seek accommodation and meeting space elsewhere. Not only does this affect revenue and the loyalty of a client, but it could cause unfavorable word-of-mouth among groups who initially sought a university venue for their conference.

University conference centers focus on repeat business because repeat groups spend more money, are easier to sell, and promote the university to others [62]. Between sixty and eighty percent of groups that use a university's conference services are sponsored by university departments for academic classes, research, and college preparatory programs. This is a common practice as most campus departments choose the university's own conference center instead of paying higher rates at an off-site location. College preparatory groups, in particular, hope that staying on campus affords student participants the dorm-lifestyle experience, which may excite students about the possibility of attending a university in the future.

Like hotels, the university location also serves as a primary source of business. Unlike hotels, however, universities provide meeting planners with many opportunities to include academic components in their meeting programs. Tour groups are least likely to choose a university for accommodations because they are not as interested in the educational atmosphere the university is likely to present. In addition, universities host religious groups, corporations, and government-related groups for all age ranges. The variety of groups choosing to host their conferences on university campuses have their own preferred communication channels. Thus, a university's conference team, and its sales personnel, in particular, must use specific marketing tools to attract target groups. Their marketing efforts must be flexible based on client interests and needs.

Email marketing is a popular tool for clients who already have an interest, such as repeat groups or academic-based groups. Constant contact via email is an effective way to keep the university fresh in clients' minds. On the other hand, trade shows can be effective to reach specific markets, such as the religious market or community organizations. Trade shows are primarily geared toward groups and meeting planners that would not normally think about university campuses for their events and conferences. 
To understand which marketing tools work best for specific audiences, universities must implement programs and methods to help track the success of each tool. The returnon-investment on most channels or tools should be measured using different methods. Monitoring email blasts being opened, website traffic, sales calls, yearly revenue, and social media posts are all useful in measuring which marketing tools to use when attracting particular clients to universities.

\subsection{Information Content}

When discussing marketing tools, the information provided to clients via these marketing tools must be clear, easy to find, and provide insight into what makes their services unique. For universities, marketing to clients who would not think of hosting meetings on campus can be a challenge. Not only must universities provide basic information about amenities, nearby tourist attractions, and photographs of facilities, but they must take this information and relate it to the campus itself. The sales and marketing department of university conference centers tends to focus on providing information about events and happenings on or near campus, such as school museums, concerts, and athletic events. On campus, many events occur within walking distance, which helps meeting attendees maximize their free time before, during, and after the event. Emphasizing the college experience is important to attracting clientele. For younger groups, the idea of staying in the dorms, eating in dining halls, and roaming the campus and college town can be thrilling. For older groups, staying on campus can provide a guest with a nostalgic college experience they may have not had the opportunity to experience first-hand. Pictures of the guest dining experience, usually part of the room package, help a university stand out from competitors because hotels may not have large dining halls or food courts for big groups.

The information about rates for conference services must be emphasized in marketing efforts for university conference centers. The lower rates and economic options are more likely to bring a large amount of business to the campus because rates for meeting rooms, facilities, exhibition hall costs, and more are the most important factor for site selection [39,52]. According to American Express Meetings and Events [63], 58\% of meeting and event planners prefer mid- and lower-tier properties for events and meetings, showing that meeting planners seriously consider budgetary constraints as they choose venues for meetings and events. Therefore, highlighting the value of staying on campus is an important marketing strategy for university conference centers targeting meeting planners who often need to adhere to a tight budget. Lower rates for room and food packages at university conference centers, especially if the university does not charge occupancy tax or services charges, allow cost-conscious meeting planners to save substantially on their meeting budget.

In marketing efforts, university conference centers tend to create shared value that connects economic performance with the university mission. At many universities, all the conference revenues or profits support university operations, which in turn support students and the teaching mission. Some universities use the revenue from conferences to help reduce student-housing costs [14]. Furthermore, the utilization of university conference centers often improves town and university relationships, while enriching the conference participants' sense of place. University conference centers create jobs for local residents and attract a clientele that further contributes to the local economy at restaurants, coffee shops, etc. Additionally, local companies can use the space to grow their own businesses by partnering with the conference center to provide other services and amenities [64]. This unique aspect of university conference operations may affect meeting planners' decision-making.

\subsection{Meeting Trends}

To remain competitive in the meetings and events market, university conference centers must identify current meeting trends and specific needs of meeting planners in the site selection process. Investing in technology is integral to keep up with millennials. 
Younger groups want instant information and fast processes (i.e., reservations, registration). Technological advances in online proposals and registrations for conferences make the planning process easier and more accessible for meeting planners. Technology in relation to audio-visual equipment and Wi-Fi connectivity is important. In addition, clients are interested in utilizing technologies such as the 3D layout of the venues, having access to specifics about the audio/visual facilities, accessing the request for proposal (RFP) online, etc. [50,54]. Most universities are up to date in technology. Many universities are already equipped with universal Wi-Fi and high-tech classroom equipment, which is an advantage because these are usually expensive amenities at hotels and other private venues.

Sustainability is another trend affecting university conference operations. With more prospective students making college decisions based on an institution's sustainability performance, campuses are already taking the initiative to ensure that green and ecological practices are implemented around the campus, including at university conference facilities. As the number of environment-friendly planners, attendees, and stakeholders continues to increase $[9,65,66]$, university conference centers must promote university-wide environmental initiatives as a selling point. Using marketing tools like social media, university conference centers can post quality videos and photographs of the locally-sourced catering menus, energy-saving meeting facilities, and various green-campus environments to help sustainability-conscious meeting planners and attendees.

\subsection{Challenges}

Some clients believe that university conference facilitates are not professional enough and thus its conference services will not meet their standards. In reality, universities are less well-known to the meeting planners, and not found on top venue lists. Finding a way to debunk these myths and improve the reputation of their conference services is a challenge for university conference centers to overcome. By attending more trade shows and increasing visibility on social media, clients will have a better idea of what a university can offer on pricing, nearby attractions, and campus happenings, as well as the high-quality service that future guests will experience.

Another challenge universities face is constant renovations and remodeling of facilities during the summer months. It is very common at universities that conference facilities, including dining halls and dormitories, are closed for annual renovation and/or remodeling because this is the only time students do not access these facilities. Such changes in availability can affect how many groups can stay during renovation and remodeling, which can hurt new business. University conference teams must communicate with potential clients about the update of available conference facilities on campus, particularly during summer months, preferably via email.

Universities want to be known for academics and research, so university conference centers, unlike hotels, have only a supportive purpose under the mission of the university [13]. This provides a challenge for marketing teams at university conference centers. With limited marketing budgets and resources, university conference teams must attract new clients and retain old business. University conference centers will always face this challenge when marketing conference services only, but by focusing on what a university can offer, they can attract groups that normally would not consider a campus for their conference.

\section{Conclusions}

Many universities in the United States are home to large conference centers that provide an array of services: meeting space, catering, accommodations, and activities. In a competitive meetings and events industry, sales, marketing, and conference managers at university conference centers must work to understand what marketing strategies can attract customers to their property. Using the Delphi method, this exploratory study has examined the various marketing tools available to university conference center personnel. The research also examined how these tools could be used to showcase the uniqueness of 
university conference centers compared to hotels and other private venues. The findings of the research indicate that using the reputation of the university, academics or athletics, can be one of the important marketing tools and strategies to stand out from competitors. In addition, while universities may be competing for the same audience as any other nearby hotels or conference venues, many of the groups are repeat clients that focus on educational programs or purposes, both internal and external. Furthermore, university venues can provide many unique advantages that can be attractive to meeting planners, stakeholders, and attendees, such as up-to-date technology, commitment to sustainability, and lower overall cost. On the other hand, stereotypes for university venues, such as low service quality and seasonal fluctuation in availability, can be challenges that university conference centers face.

The meeting environment changes dramatically every day. Keeping up with current trends is integral to remain competitive in this market. With new and better social media opportunities and innovative technology, those working at university conference centers must diversify marketing efforts to keep up with growth and compete with hotels and other meeting venues.

\section{Limitations and Future Research}

Although this exploratory study is the first of its kind in convention and event research, it is not free of drawbacks. The major limitation for this study is its small sample size: eight meeting and event professionals working for three university conference centers located in the same geographical area. Thus, a natural extension of this study is to include and evaluate the views of more professionals working at university conference centers across the United States. Responses may vary for personnel working at universities in different regions of the United States based on what amenities are offered in the surrounding area. Another future research possibility would include marketing professionals working in hotels. Using the same questionnaire, re-worded to represent a hotel and not a university, researchers could compare answers to identify differences in which marketing tools work best and which types of clients the marketing tools help attract to each venue.

Lastly, future research efforts could be devoted to answering these questions: How can university conference centers accurately measure the amount of business each marketing channel brings to the university? What are the differences between marketing procedures and policies used by public universities versus private universities? How do small universities in less well-known areas use marketing to attract clients wanting to host conferences in nearby, more widely-known towns? How do guests at conferences hosted by universities versus hotels perceive their overall experiences? What is the inter-relationship between these variables? Research on conference and meeting venues is abundant, but more work on the benefits and challenges of university conference centers, specifically, would undoubtedly benefit the academic community in tourism and hospitality.

Author Contributions: Conceptualization, M.S. and M.J.L.; methodology, H.C. and M.J.L.; software, H.K.; validation, M.S. and H.C.; formal analysis, M.J.L.; investigation, M.S. and H.K.; resources, M.S.; data curation, M.J.L.; writing—original draft preparation, M.S.; writing—review and editing, H.C.; visualization, H.C.; supervision, M.J.L. All authors have read and agreed to the published version of the manuscript.

Funding: This research received no external funding.

Institutional Review Board Statement: Not applicable.

Informed Consent Statement: Not applicable.

Data Availability Statement: Not applicable.

Conflicts of Interest: The authors declare no conflict of interest. 


\section{Appendix A. Marketing Tools and Strategies of the University Conference Centers}

Appendix A.1. Marketing Tools

- 1A. Describe the marketing tools that your department uses in order to market the services provided by your university.

- $1 \mathrm{~B}$. Which of these tools do you find most beneficial to your university and why? Least beneficial?

\section{Appendix A.2. Clients}

- 2A. Describe the types of clients and groups that come to your university for conferences.

- $2 B$. Do you believe that particular marketing tools work better with some clients than with others? Please explain why or why not (provide examples).

- $\quad 2 \mathrm{C}$. Are you able to measure if your marketing tools are successful when attracting potential clients? If so, please explain.

\section{Appendix A.3. Information Content}

- $\quad 3 \mathrm{~A}$. What information do you provide to your clients via these marketing tools?

- $3 \mathrm{~B}$. What type of information do you feel should be provided when marketing a university campus in order to stand out from private-sector competitors who provide similar conference services? What are the advantages that staying on a university campus would provide guests?

\section{Appendix A.4. Trends}

- $\quad 4 \mathrm{~A}$. What are some current trends, relating to hospitality and marketing, that university marketing teams and sales personnel could take advantage of?

- $4 \mathrm{~B}$. What are future opportunities you believe university conference centers have in comparison to private-sector properties.

\section{Appendix A.5. Challenges}

- 5A. What are the challenges the universities face when marketing themselves to current and future clients?

- $\quad$ 5B. How can your university be improved in marketing based on current trends and challenges?

\section{References}

1. Bradley, A.; Hall, T.; Harrison, M. Selling cities: Promoting new images for meetings tourism. Cities 2002, 19, 61-70. [CrossRef]

2. Getz, D. Event tourism: Definition, evolution, and research. Tour. Manag. 2008, 29, 403-428. [CrossRef]

3. Bagire, V.; Byarugaba, J.; Kyogabiirwe, J. Organizational meetings: Management and benefits. J. Manag. Dev. 2015, 34, 960-972. [CrossRef]

4. Fractl. 4 Key Benefits to Attending Marketing Events, Meetings, and Conferences. Available online: https://www.frac.tl/keybenefits-attending-marketing-events / (accessed on 22 May 2021).

5. Kim, D.Y.; Morrison, A.M.; Mills, J.E. Tiers or tears? An evaluation of the web-based marketing efforts of major city convention centers in the U.S. J. Conv. Exhib. Manag. 2004, 5, 25-49.

6. Jensen, C.; Diiulio, R.; Cain, S. New and Improved Convention Centers in the Horison. Trade Show Executive. Available online: http:/ / online.fliphtml5.com/brun/hjij/\#p=59 (accessed on 22 May 2021).

7. Statista. Exhibition, Convention, \& Meeting Industry Statistics \& Facts. Available online: https://www.statista.com/topics/1413 / exhibitions-convention-and-meetings/\#dossierSummary (accessed on 22 May 2021).

8. Dwyer, L.; Forsyth, P.; Spurr, R. Estimating the Impacts of Special Events on an Economy. J. Travel Res. 2005, 43, 351-359. [CrossRef]

9. Sangpikul, A.; Kim, S. An Overview and Identification of Barriers Affecting the Meeting and Convention Industry in Thailand. J. Conv. Event Tour. 2009, 10, 185-210. [CrossRef]

10. Qiuju, L.; Jiawen, P.; Wenmin, J. An empirical study on the economic impact of the events with input-output model: A case study of Canton Fair. China 2011, 4, 487-503. 
11. Oxford Economics. Economic Significance of Meetings to the US Economy. Available online: https://www.ahla.com/sites/ default/files/Economic\%20Signifcance\%20of\%20Meetings.pdf (accessed on 24 May 2021).

12. Clark, J.D. What are Cities Really Committing to When They Build a Convention Center? J. Conv. Event Tour. 2007, 8, 7-27. [CrossRef]

13. Lloyd-Jones, A. The Benefits and Challenges of University Hotels and Conference Centers. HVS Website. Available online: https: / / www.hvs.com/article/3263-the-benefits-and-challenges-of-university-hotels-and-conference-centers (accessed on 22 May 2021).

14. Cooper, M. 10 Reasons Why Academic Venues Are Excellent Conference Locations. Available online: https: / www.iacconline. org/iacc-blog/10-reasons-why-academic-venues-are-excellent-conference-locations (accessed on 22 May 2021).

15. International Association of Conference Centers. IACC-CBRE Conference Venue Trends 2016 Edition. Available online: https: //www.hotel-online.com/press_releases/release/iacc-trends-in-the-conference-venue-industry/ (accessed on 22 May 2021).

16. Leong, K.C. Advance Placement. Smart Meetings. Available online: http:/ / www.smartmeetings.com (accessed on 22 May 2021).

17. Academic Venue Solutions. Why Academic Venues Are Great Places to Host Events. Available online: https:// academicvenuesolutions.co.uk/blog/why-academic-venues-are-great-places-to-host-events (accessed on 22 May 2021).

18. Fenich, G. Meetings, Expositions, Events, and Conventions: An Introduction to the Industry, 5th ed.; Pearson: Boston, MA, USA, 2019.

19. Crouch, G.I.; Brent Ritchie, J.R. Convention site selection research: A review, conceptual model, and propositional framework. J. Conv. Exhib. Manag. 1997, 1, 49-69. [CrossRef]

20. Lee, M.J.; Back, K. A review of economic value drivers in convention and meeting management research. Int. J. Contemp. Hosp. Manag. 2005, 17, 409-420. [CrossRef]

21. Draper, J.; Dawson, M.; Casey, E. An Exploratory Study of the Importance of Sustainable Practices in the Meeting and Convention Site Selection Process. J. Conv. Event Tour. 2011, 12, 153-178. [CrossRef]

22. DiPietro, R.B.; Breiter, D.; Rompf, P.; Godlewska, M. An Exploratory Study of Differences among Meeting and Exhibition Planners in their Destination Selection Criteria. J. Conv. Event Tour. 2008, 9, 258-276. [CrossRef]

23. Todd. 7 Major Venue Types that Unique Venues Represents. Available online: https://www.uniquevenues.com/blog/7-venuetypes-infographic (accessed on 22 May 2021).

24. Adhya, A. The Public Realm as a Place of Everyday Urbanism: Learning from Four College Towns. Doctoral Dissertation, University of Michigan, Ann Arbor, MI, USA, 2008.

25. Elston, K.; Draper, J. A Review of Meeting Planner Site Selection Criteria Research. J. Conv. Event Tour. 2012, 13, 203-220. [CrossRef]

26. Roberts, B.H. Managing Systems of Secondary Cities: Policy Responses in International Development; Cities Alliance: Brussels, Belgium, 2014.

27. Jeff. 10 Reasons to Meet at the Marcum Hotel \& Conference Center. Available online: https://www.uniquevenues.com/blog/10 -reasons-meet-marcum-hotel-conference-center (accessed on 22 May 2021).

28. Pan, S. The Role of TV Commercial Visuals in Forming Memorable and Impressive Destination Images. J. Travel Res. 2011, 50, 171-185. [CrossRef]

29. Wicks, B.E.; Schuett, M.A. Examining the role of tourism promotion through the use of brochures. Tour. Manag. 1991, 12, 301-312. [CrossRef]

30. Lee, S.; Close, A.G.; Love, C. How Information Quality and Market Turbulence Impact Convention and Visitors Bureaus' Use of Marketing Information: Insights for Destination and Event Marketing. J. Conv. Event Tour. 2010, 11, 266-292. [CrossRef]

31. Rogers, T.; Davidson, R. Marketing Destinations and Venues for Conferences, Conventions and Business Events; Routlege: New York, NY, USA, 2015.

32. Tinnish, S.M.; Mangal, S.M. Sustainable Event Marketing in the MICE Industry: A Theoretical Framework. J. Conv. Event Tour. 2012, 13, 227-249. [CrossRef]

33. Barber, P.; Wallace, L. The power of word-of-mouth marketing. Am. Libr. 2009, 40, 36-39.

34. Manners, B.; Kruger, M.; Saayman, M. Managing the Beautiful Noise: Evidence from the Neil Diamond Show! J. Conv. Event Tour. 2012, 13, 100-120. [CrossRef]

35. Pan, B.; Maclaurin, T.; Crotts, J.C. Travel Blogs and the Implications for Destination Marketing. J. Travel Res. 2007, 46, 35-45. [CrossRef]

36. Kim, Y.-S.; Lee, Y.-Y.; Love, C. A Case Study Examining the Influence of Conference Food Function on Attendee Satisfaction and Return Intention at a Corporate Conference. J. Conv. Event Tour. 2009, 10, 211-230. [CrossRef]

37. Zhu, M.; Lai, S. A study about the EWOM influence on tourism destination choice. In Proceedings of the 2009 International Conference on Electronic Commerce and Business Intelligence, Beijing, China, 6-7 June 2009.

38. Chiu, L.K.; Ananzeh, O.A. Evaluating the relationship between the role of promotional tools in MICE tourism and the formation of the touristic image of Jordan. Tour. Innov. J. 2012, 5, 59-73.

39. Alexander, A.C.; Kim, D.-Y.; Groves, J. Individual and Organizational Characteristics Influencing Event Planners' Perceptions of Information Content and Channel Choice. J. Conv. Event Tour. 2012, 13, 16-38. [CrossRef]

40. Sarmento, M.; Farhangmehr, M.; Simões, C. Participating in Business-to-Business Trade Fairs: Does the Buying Function Matter? J. Conv. Event Tour. 2015, 16, 273-297. [CrossRef]

41. Tanner, J.F., Jr.; Chonko, L.B.; Ponzurick, T.V. A learning model of trade show attendance. J. Conv. Exhib. Manag. 2001, 3, 3-26. [CrossRef] 
42. Gretzel, U.; Yuan, Y.-L.; Fesenmaier, D.R. Preparing for the New Economy: Advertising Strategies and Change in Destination Marketing Organizations. J. Travel Res. 2000, 39, 146-156. [CrossRef]

43. Wang, Y.; Fesenmaier, D.R. Identifying the Success Factors of Web-Based Marketing Strategy: An Investigation of Convention and Visitors Bureaus in the United States. J. Travel Res. 2006, 44, 239-249. [CrossRef]

44. Solaris, J.; Cross, B. The Event App Bible 2018. Available online: https://www.eventmanagerblog.com/event-apps (accessed on 22 May 2021).

45. Anuar, J.; Musa, M.; Khalid, K. Smartphone's Application Adoption Benefits Using Mobile Hotel Reservation System (MHRS) among 3 to 5-star City Hotels in Malaysia. Procedia Soc. Behav. Sci. 2014, 130, 552-557. [CrossRef]

46. Dellarocas, C. The Digitization of Word of Mouth: Promise and Challenges of Online Feedback Mechanisms. Manag. Sci. 2003, 49, 1407-1424. [CrossRef]

47. Lee, H.-R.; McKercher, B.; Kim, S.S. The relationship between convention hosts and professional conference organizers. Int. J. Hosp. Manag. 2009, 28, 556-562. [CrossRef]

48. Fodness, D.; Murray, B. A Model of Tourist Information Search Behavior. J. Travel Res. 1999, 37, 220-230. [CrossRef]

49. Breiter, D.; Milman, A. Attendees' needs and service priorities in a large convention center: Application of the importanceperformance theory. Tour. Manag. 2006, 27, 1364-1370. [CrossRef]

50. Lee, S.; Kim, J.-H.; Parrish, C. Are You Ready for the Extra Inning? An Exploratory Study of the Evaluation of Professional Sport Teams' Websites as Marketing Tools to Prospective Meeting/Event Customers. J. Conv. Event Tour. 2012, 13, 270-289. [CrossRef]

51. Mayaka, T. Factors Influencing Choice of Conference Venues: A Case of Meetings, Incentives, Conventions and Exhibitions (Mice) Customers. Ph.D. Thesis, United States International University-Africa, Nairobi, Kenya, 2018.

52. Lee, H.; Lee, J.-S. An exploratory study of factors that exhibition organizers look for when selecting convention and exhibition centers. J. Travel Tour. Mark. 2017, 34, 1001-1017. [CrossRef]

53. Cai, L.A.; Feng, R.; Breiter, D. Tourist purchase decision involvement and information preferences. J. Vacat. Mark. 2004, 10, 138-148. [CrossRef]

54. Lindgaard, G.; Fernandes, G.; Dudek, C.; Brown, J. Attention web designers: You have 50 milliseconds to make a good first impression! Behav. Inf. Technol. 2006, 25, 115-126. [CrossRef]

55. Dalkey, N.; Helmer, O. An Experimental Application of the DELPHI Method to the Use of Experts. Manag. Sci. 1963, 9, 458-467. [CrossRef]

56. Hasson, F.; Keeney, S.; McKenna, H. Research guidelines for the Delphi survey technique. J. Adv. Nurs. 2000, 32, 1008-1015. [CrossRef]

57. Ritchie, J.B.; Goeldner, C.R. Travel, Tourism, and Hospitality Research: A Handbook for Managers and Researchers, 2nd ed.; Wiley: New York, NY, USA, 1994.

58. Clark, J.D. Formulating strategic marketing direction for a second-tier convention center: The Hickory (North Carolina) metro convention center. J. Conv. Event Tour. 2008, 9, 148-160. [CrossRef]

59. Skulmoski, G.; Hartman, F.T.; Krahn, J. The Delphi Method for Graduate Research. J. Inf. Technol. Educ. Res. 2007, 6, 1-21. [CrossRef]

60. Mackey, A.; Gass, S.M. Second Language Research: Methodology and Design, 2nd ed.; Routledge: New York, NY, USA, 2015.

61. Creswell, J.W. Educational Research: Planning, Conducting, and Evaluating Quantitative and Qualitative Research, 4th ed.; Pearson: Boston, MA, USA, 2012.

62. Nethercott, R. Five Reasons Why Repeat Customers Are Better than New Customers. Available online: https://blogs. constantcontact.com/repeat-customers/ (accessed on 22 May 2021).

63. American Express Meetings \& Events. 2019 Global Meeting \& Events Forecast. Available online: https://3rxg9qea18zhtl6s2u8 jammft-wpengine.netdna-ssl.com/wp-content/uploads/2018/11/2019-Global-Meetings-Forecast-Final-US121-1.pdf (accessed on 22 May 2021).

64. Rosenberg. Campus Hotels/Conference Centers: Why, How, Trends, and Where We Go from Here. Available online: https: / / www.bdconnect.com/campus-hotels-conference-centers-why-how-trends-and-where-we-go-from-here/ (accessed on 19 June 2021).

65. Rittichainuwat, B.; Mair, J. An Exploratory Study of Attendee Perceptions of Green Meetings. J. Conv. Event Tour. 2012, 13, 147-158. [CrossRef]

66. Buathong, K.; Lai, P.-C. Event sustainable development in Thailand: A qualitative investigation. J. Hosp. Leis. Sport Tour. Educ. 2019, 24, 110-119. [CrossRef] 